CLASS STRUGGLE

IN HOLLYWOOD 
THIS PAGE INTENTIONALLY LEFT BLANK 


\section{GERALD HORNE}

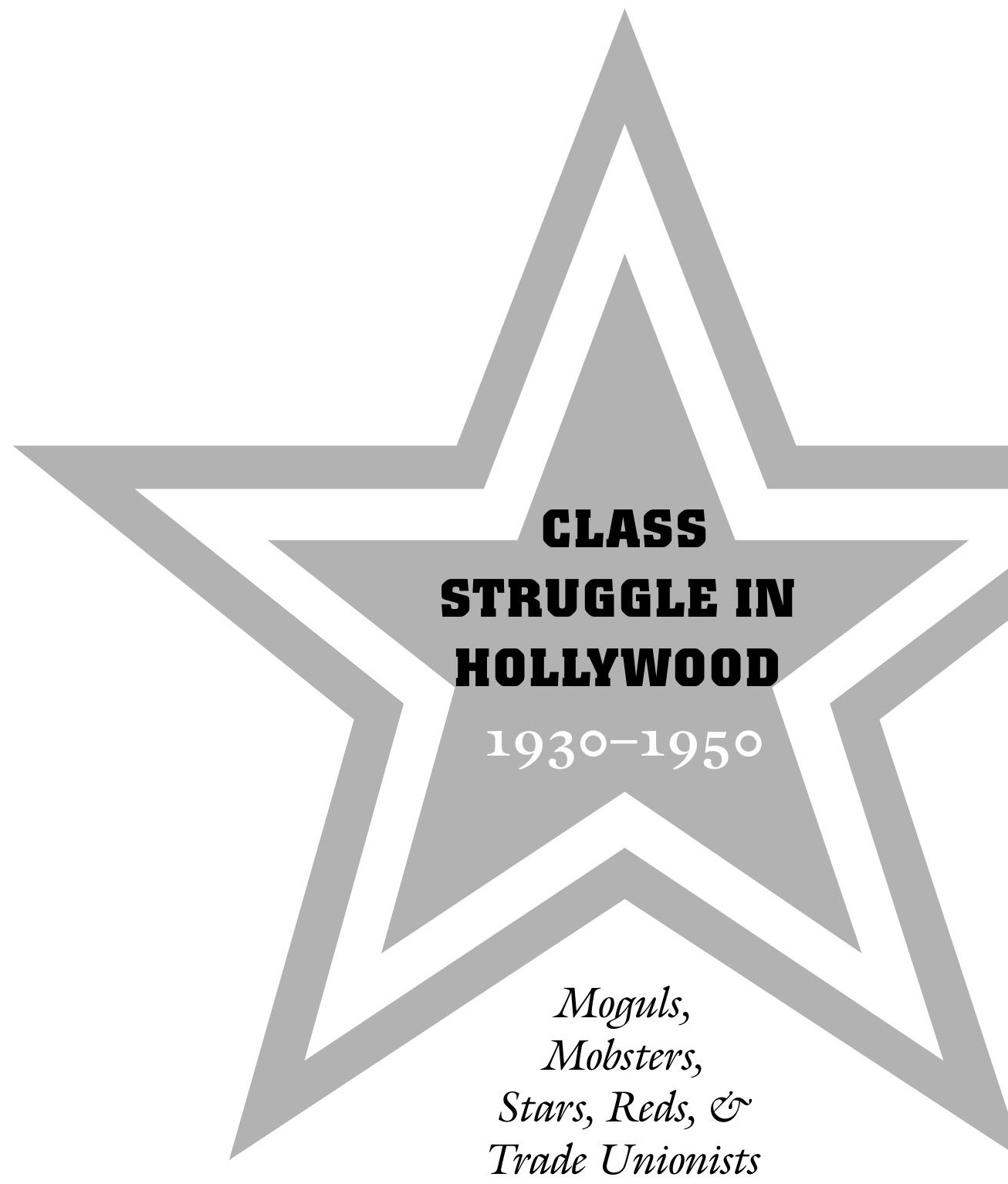

University of Texas Press, Austin 
Copyright (C) 200I by the University of Texas Press All rights reserved

Printed in the United States of America

First edition, 200I

Requests for permission to reproduce material from this work should be sent to Permissions, University of Texas Press, P.O. Box 7819, Austin, TX 78713-7819.

(a) The paper used in this book meets the minimum requirements of ANSI/NISO Z39.48-I992 (RI997) (Permanence of Paper).

LIBRARY OF CONGRESS CATALOGING-IN-PUBLICATION DATA

Horne, Gerald.

Class struggle in Hollywood, I930-1950 : moguls, mobsters, stars, Reds, and trade unionists / by Gerald Horne. - Ist. ed. p. $\quad \mathrm{cm}$.

Includes bibliographical references and index. ISBN 0-292-73I37-X (cl. : alk. paper) ISBN 0-292-73I38-8 (pbk. : alk. paper)

I. Motion picture industry-Employees-Labor unionsCalifornia-Los Angeles. I. Title.

PNI993.5.U65 H67 200I

33I.88'II79I43'0979494-dc2I 